\title{
The European Crisis and Turkey's Unpredictable Role in the Balkans
}

\author{
ILYA ROUBANIS*
}

\begin{abstract}
This paper discusses Turkey's role in the Balkans as part of the broader narrative of European integration. 'Europeanization' in the early 2000s was a political platform that was instrumental in allowing Turkey to forge a peace between the country's established elite and moderate political Islam. In the context of Turkey's alienation from the project of European integration, the relationship between Europe and Turkey is becoming narrowly transactional and there is no longer a 'community building' dynamic. Instead, the region emerges as a canvas of competing influences and mutually exclusive choices between Ankara and Brussels that ultimately contribute to 'Balkanization.'
\end{abstract}

urope remains a normative superpower, ${ }^{1}$ setting standards and shaping political norms well beyond its member states. Even amid an undeniable crisis of the project of European integration, both within member states and in the regions around the EU, the functionalist premise still appears valid. Integration in one policy area creates a spillover effect causing member states and associated partners to coordinate policy in another, paving the way for an ever-closer union. Association Agreements, Deep and Comprehensive Free Trade Agreements (DCFTAs), and a Customs Union area create a space of free trade around Europe that has a profound effect in
Europe, well beyond the EU. However, as the Brexit process suggests, functional interdependence does not determine political cohesion, especially in an increasingly multipolar world order. While Turkey is in many respects a European economy, the fact that Ankara's prospects for EU membership are dimming -along with those of the Western Balkan states- changes the frame of political engagement, providing scope for colliding or even zero-sum encounters.

For more than a decade, there has been a Turkish 'post-Ottoman' vision of the Balkans that was not in conflict with Europeanization per se. Turkey's ambition in the region to stand out
* Institute of International Relations (IDIS), Greece

Insight Turkey Vol. 21 / No. 2 / 2019, pp. $75-89$ 


\section{What is clear from cases such}

as the Dutch referendum

against Ukraine's Association

Agreement and the UK's

2016 Leave campaign is that

enlargement has become a

heated debate often framed

by anti-immigration rhetoric as a protector of Muslim minorities and renew its political and economic bonds with the region could be enveloped into a greater narrative of regional integration. However, when signaled out as a 'European other', Turkey is often driven to make the Balkans the testing ground of a more zero-sum framing of diplomatic relations with Brussels. This article makes the constructivist argument that Turkey's perception of 'national interests' in the Balkans makes part of a 'mutually constitutive' dynamic between Europe and Turkey. As far as Turkey is not part of the community-building process, it may be seen as part of an alternative cluster of bilateral relationships that undermines the narrative of functional interdependence.

\section{What Europeanization?}

One should not confuse functional linkage with structurally enduring relations. A policy-by-policy process of integration does not tell the whole story of European integration.
Enlargement does not merely 'assimilate' states in a rule-based political order but also causes the EU to reflect on its role, its mission, and its institutional apparatus. With the British, Irish, and Danish accessions, the EU moved to create a European Regional Fund and to reform the common agricultural policy. The arrival of Greece in 1981 and of Spain and Portugal in 1986 led to initiatives for a substantial cohesion policy, as a precondition of realizing the Single Market and guaranteeing democracy. But faced with the biggest wave of enlargement in 2004 -the so-called big bang expansion- Europeanization became a reform project.

Fifteen years following the big bang enlargement, the EU has successfully addressed the fear that consensus-driven bureaucratic processes might become dysfunctional. As newcomers came into the EU, political stakeholders were quickly assimilated. Parties found their place in the European Parliament, in the Council of Ministers member-states joined time-tested alliances, and the Commissioners empowered by adequate technocratic support rose to the challenge. Where concerns persist and have in fact intensified, is the ability of EU institutions to effectively monitor the process of member-state-building on a micro-governance level, where concerns are raised about corruption, rule of law structures, tax evasion, and the like. ${ }^{2}$

Given that failure, the promise of EU membership has lost much of its credibility both for Turkey and 
other Balkans states. Recently, the chairman of the Centre for Liberal Strategies in Sofia, Ivan Krastev, made a useful distinction between 'pessimists' and 'optimists' on the subject of EU membership: "optimists believe Turkey will join during the Albanian EU presidency, while pessimists believe Albania will join during the Turkish EU presidency." In the current context, to suggest that the EU suffers from "enlargement fatigue" is an understatement. In the EU-Western Balkans Summit of May 2018, in Sofia, Chancellor Angela Merkel offered assurances that Balkan countries retain their entitlement to EU membership, as promised in the Thessaloniki Council of June 2013. However, the President of the European Council, Donald Tusk, was careful not to overstate the "unrealistic" perspective of fast track membership. ${ }^{4}$ In June 2018, France and the Netherlands blocked the opening of EU accession talks with North Macedonia and Albania, calling for more reforms that would bolster the rule of law and transparency. ${ }^{5}$

The jury is still out on whether it is Turkey and the Balkans that are failing to reform, or the EU that lacks the political resolve to drive the transitional process. What is clear from cases such as the Dutch referendum against Ukraine's Association Agreement ${ }^{6}$ and the UK's 2016 Leave campaign is that enlargement has become a heated debate often framed by anti-immigration rhetoric. The EU's consensus-driven policy framework undermines the credibility of the enlargement process, a weakness that was already identified since the signature and ratification of the Lisbon Treaty.

As the European sovereign debt crisis was unfolding in 2009, President Sarkozy underlined the need for the union to act as a single international actor, by extending the principle of unanimity in the Council to qualified majority voting, increasing the scope for co-decision between the European Council and the European Parliament, reducing the number of Commissioners, creating the post of the President of the European Council and creating a single and empowered office of an EU foreign minister. The underlying theme was that consensus was a fragile foundation for an ever-growing union and there was increasing demand for majority-driven decision making. He referred explicitly to enlargement: "No Lisbon Treaty, no enlargement... I would find it very strange for a Europe of 27 that has trouble agreeing on workable institutions to agree on adding a $28^{\text {th }}$, a $29^{\text {th }}$, a $30^{\text {th }}$, a $31^{\text {st }}$, which would definitely make things worse."

After a decade of economic crisis across the EU, the term 'enlargement fatigue' often goes hand-in-hand with the admission that Europe has lost confidence in the combined dynamic of an ever-encompassing and ever-closer union. In the Sofia Summit of 2018, EU leaders narrowed the discussion to a transactional agenda. There was a focus on the need to ensure that ISIS fighters returning from Syria do not go on to pursue terrorist activity in Europe. There was great 


\section{TÜRKIYE- AB YÜKSEK DÜZEYLI SIYASI DIYALOG TOPLANTISI}

\section{TURKEY- EU HIGH LEVEL PQITICAL DIALOGUE MEETING}

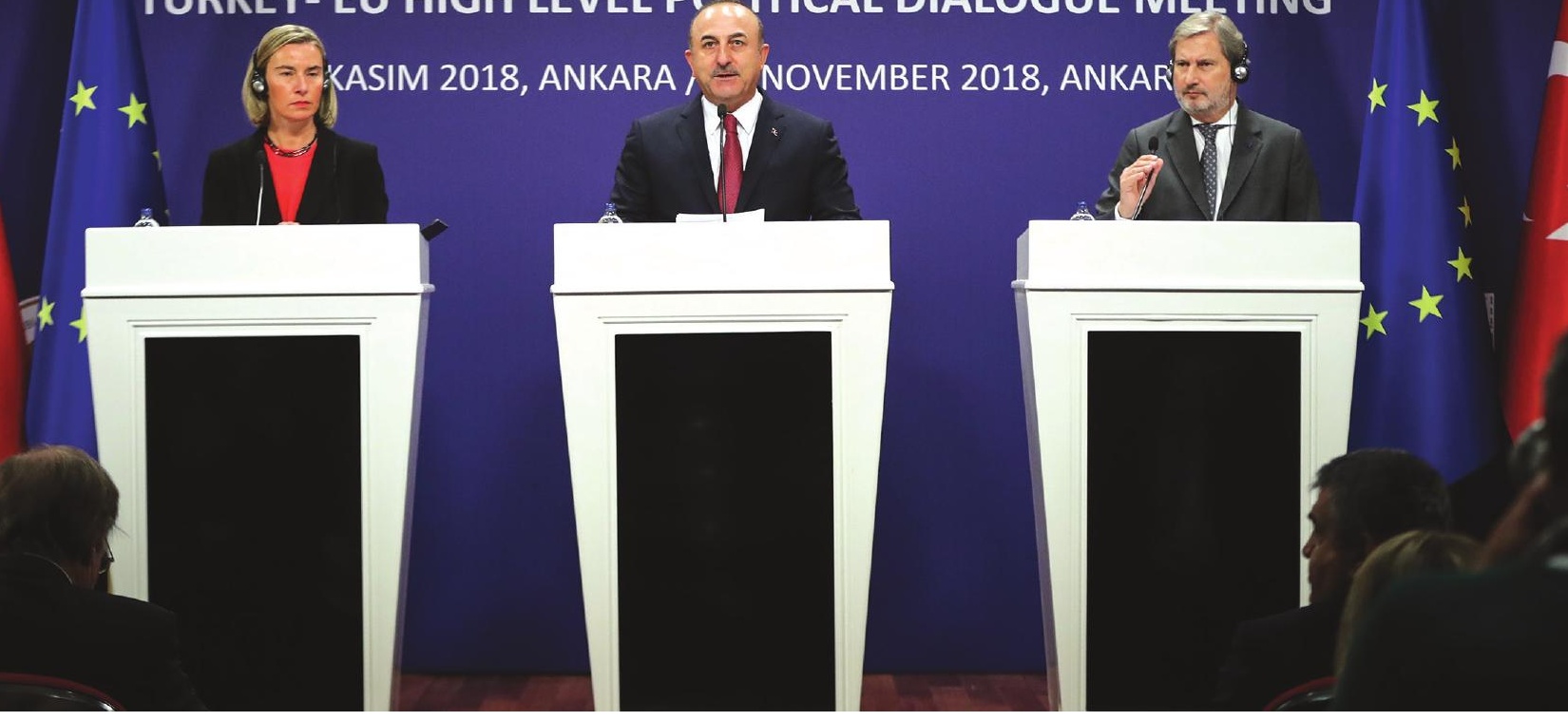

Turkish FM

Çavuşoğlu (C), EU

Neighborhood

Policy Minister

Hahn (R), High

Representative

of the EU for

Foreign Affairs

and Security

Policy Mogherini

(L) hold a joint

press conference

within "Turkey-

EU High-Level

Political Dialogue

Meeting" in

Ankara, on

November 22,

2018.

CEM ÖZDEL/

AA Photo interest in ensuring that Turkey and Balkan states continue to disrupt the flow of migration into Western Europe. There were extensive discussions on how Balkan states would be assisted for their cooperation. However, there was little appetite to discuss enlargement.

"I don't want a Balkans that turns toward Turkey or Russia; but I don't want a Europe that is functioning with difficulty as 28 and tomorrow as 27 , would decide that we can continue to gallop off, to be tomorrow 30 or 32, with the same rules," French President Emmanuel Macron told the European Parliament in April 2018. "I do not think 2025 is a realistic date for the EU enlargement; more important is the progress that has been achieved by the candidates," said Chancellor Angela Merkel on May 17, in Sofia. ${ }^{8}$ In parallel, Washington's commitment to the Euro-Atlantic "community" is waning.
Addressing the World Economic Forum in January 2019, U.S. Secretary of State Mike Pompeo made clear that pre-existing alliances and institutions must serve national interests. "Nations matter," Pompeo professed, making clear that the United States stands critically against globalization. ${ }^{9}$ That statement was consistent with a long-standing skepticism expressed by Washington both vis-à-vis the United Nations and NATO. At times, this criticism against international organizations is focused on issues, such as member state defense expenditure, in which Turkey stands out as one of the five to eight countries that consistently meet the two percent of GDP threshold set by allies. But, this does not mean that Turkey sees eye to eye with Washington.

Washington objects to Turkey's S-400 deal with Russia while Ankara vehemently condemns Washington's strategic alliance with the PKK's Syrian 
affiliate (People's Protection Units, YPG). ${ }^{10}$ But perhaps, the most bitter standoff between the two NATO allies is over Turkish demands for the extradition of Fetullah Gülen, which Ankara linked to the release of the Pastor Andrew Brunson. ${ }^{11}$ In August 2018, President Erdoğan went as far as to threaten that Turkey may look beyond NATO for partners. ${ }^{12}$ That is not the first time this threat has been put on the table. In August 2016, President Erdoğan wondered "what kind of strategic partners are we" while in a much-cited interview with Hürriyet, retired Rear Admiral Cem Gürdeniz suggested that there was a strong movement in the Armed Forces that views Turkish interests as more aligned to "Eurasia."13 Setting a strictly national foreign policy trajectory that prioritizes national defense capability, Turkey appears willing to challenge NATO at the "molecular level" of military interoperability. ${ }^{14}$ The aftermath of the coup attempt has also seen European Parliament insistence on freezing the process of enlargement with Turkey. On April 26, 2017, members of the European Parliament called on the European Union's Enlargement Commissioner Johannes Hahn to seek alternatives to Turkey's accession. Opening the debate, European Parliament President Antonio Tajani insisted that "Europe is not an Islamophobic continent and is not closing the door on the Turkish people," but he insisted that Turkey must respond to human rights criticism. The leader of the European Conservatives and Reformists (ECR) Group, Syed Kamall, called for "a more difficult relation-

\section{While the 'taking our} jobs' cliché was extremely relevant for public opinion in the countdown and the aftermath of the 2004 big bang enlargement towards Eastern Europe, the prospect of welcoming Turkish citizens seems to evoke unique resistance

ship" with Turkey where cooperation would continue but "the distant goal of EU membership" would not be on the table. In October 2018, the European Parliament voted to withhold $€ 70$ million in pre-accession funding even as member states and the European Commission are trying to normalize relations with Turkey.

\section{Turkey as a 'European 0ther'}

It is not accurate to suggest that Euro-Turkish relations have had a difficult two years. Indeed, the question of Turkish EU-membership has been central to a broader discussion about the nature of the union. Today it is hard to believe that it was Britain which historically championed enlargement, especially the Turkish candidacy. In 1991, Prime Minister John Major made the case for a Community to "open to all the democratic countries of Europe."15 The 'wider, 


\section{To reduce the effect of}

Europeanization in Turkey

to the prospect of imminent

EU membership is naìve and

perhaps shallow. For Turkey,

being part of Europe has been

an iconoclastic movement as

old as the Republic itself not deeper' mantra was consistent with the idea that enlargement focused minds on the single market. "We shall put in place the last measures needed to complete the single market-a single market that will extend way beyond the borders of the Twelve, even before the new member states join," Major told the House of Commons in 1991.

Fifteen years later, the Economist argued that EU enlargement towards Turkey but also the Balkans and even Ukraine was "a natural drive" that no one had the political capital to delay. ${ }^{16}$ Given a long British tradition of spearheading the drive for Turkish EU membership, it is ironic that the 2016 Leave campaign raised the specter of imminent Turkish membership to the EU to heighten the fear of "the floodgates of immigration," 17 while pointing to the exit. ${ }^{18}$ On the other side of the argument, the British prime minister was warning public opinion that Turkish imminent EU membership was an idle threat, that is, a lie that people should not take seriously. "I really feel strongly about this, as people are getting through their letter boxes leaflets from Leave saying 'Turkey's going to join the EU' - not true," said David Cameron. ${ }^{19}$

Anti-enlargement and anti-immigration rhetoric have always gone handin-hand. President Nicolas Sarkozy often blended anti-Turkish with anti-enlargement rhetoric, ${ }^{20}$ presumably to shield the French centre-right from its continuous leakage of voters to the Front National. "I want to say that Europe must give itself borders, that not all countries have a vocation to become members of Europe, beginning with Turkey which has no place inside the European Union," Sarkozy said during the 2007 Presidential campaign. ${ }^{21}$ That Turkey's membership of the EU is "unthinkable" has been a consistent feature of his political message. Chancellor Merkel too did not shy away from questioning Turkey's entitlement to an EU membership during her first term. ${ }^{22}$

Part of this language of Europe's essential incompatibility with Turkey has its roots in a long tradition of colonial and post-colonial discourse. A moment of clarity emerged in 2004, when the U.S. President George W. Bush stated that Turkey belongs in the EU and that Europe is "not the exclusive club of a single religion." A day later, he received the answer from President Jacques Chirac, which went as follows:

If President Bush really said that in the way that I read, then not only did he 
go too far, but he went into territory that isn't his (...) It is not his purpose and his goal to give any advice to the $\mathrm{EU}$, and in this area it was a bit as if I were to tell Americans how they should handle their relationship with Mexico. ${ }^{23}$

Chirac's allusion to Turkey as the Mexico of Europe brings light to another media frame that informs European public opinion. A few decades of constructivist literature amply demonstrate that opinion poll respondents address questions in a manner consistent to their emotionally significant reference-group, which is often the nation. In this context, it is anticipated that migrants are conceived by Western European constituencies as a threat to collective national goods, such as education, jobs, and welfare.

While the 'taking our jobs' cliché was extremely relevant for public opinion in the countdown and the aftermath of the 2004 big bang enlargement towards Eastern Europe, the prospect of welcoming Turkish citizens seems to evoke unique resistance. Turks are seen as particularly threatening to ingroup symbols and myths -religion, culture, and way of life- especially in countries that have experienced large migration waves in the 1960s. For example, the least negative public opinion attitude towards Turkish EU accession is observed in Spain, while the largest opposition is observed in Germany, Austria, and the Netherlands. ${ }^{24}$ Europe's crisis heightens anti-Turkish prejudice, just as sovereigntist, anti-immigration, and
anti-Islam parties gain political influence. In sum, the question of Turkey is not only polarizing but also a rallying flag for Europe's sovereigntist right.

\section{Turkey as a 'European Insider'}

To reduce the effect of Europeanization in Turkey to the prospect of imminent EU membership is naïve and perhaps shallow. For Turkey, being part of Europe has been an iconoclastic movement as old as the $\mathrm{Re}$ public itself. The status of the army as the guardian of the constitution and guarantor of the Republic's western trajectory is not merely symbolic. Turkey has a long history of military interventions in politics -1960, 1971, 1980-1983, 1997- which, rather than resulting in long-term direct military rule, were usually short periods of institutional reform followed by a dictated transition to civilian government. This institutional veto power was imbued with a sense of cultural significance as it was almost always recognized in the name of preserving the course of a certain kind of Turkey.

Prior to the demise of the Ottoman Empire and the emergence of the Turkish Republic, the very term 'Turk' was a diminutive adjective referring to the Muslim and largely illiterate peasants of Anatolia. ${ }^{25}$ Turkish nationalism essentially invested this term with racial and national significance. But, the dual significance of the term was persevered, haunting modern Turkish society. However, in the late 1990s, and early 2000s 
the interchangeable use of the term 'Europeanization' with 'modernization' in Turkey provided a window of opportunity with domestic political resonance. By engaging with the $\mathrm{EU}$, there were hopes that the dual significance of the term 'Turk' could achieve a viable synthesis.

Ankara implemented a series of political reforms ${ }^{26}$ paving the way for the Customs Union in December 1995. ${ }^{27}$ But when the Turkish military dictated the resignation of the Islamic government in 1997, the process of EU negotiations came to a standstill and moderate political Islam realized that Europe was not merely a project that should be of interest to the 'other half of Turkey'. Gaining the status of an EU member state in the early 2000s provided the moderate Islamic AK Party movement with a legitimating platform for the modernization or 'Europeanization' of civil-military relations.

The AK Party government more than welcomed EU demands for civilian control over the military, the diminution and reform of the National Security Council, the reform of the judiciary, and the reform of the office of the President. Erdoğan's first government set out to align Turkey with European rule of law standards, with Islam but not against modernity, and perhaps for Europe, but not against Turkey. AK Party portrayed itself as an Islamic version of European Christian-Democracy, as a champion of individual rights, the rule of law, and traditional values. ${ }^{28}$ How powerful resource the process of EU nego- tiations was for the AK Party movement was amply demonstrated in April 28, 2007, when rumors started of an imminent military intervention and tanks made their presence in the streets of İstanbul. The army stood down because it was made clear that another intervention would be the end of the road for Turkey's European project. Europeanization in Turkey appeared to be valued as a process rather than merely as a means to an end.

And there were broader implications for the 'West' and democratization from Turkey's 'success story.' As the Arab spring saw the collapse of dictatorial regimes across the Middle East, an article in El Pais hailed Turkey rather than the EU as the model for democratic development in the Islamic world. ${ }^{29}$ After all, Turkey was able to guarantee not only upward social mobility and economic development, but also substantial individual rights. Having transcended the contradiction between Islam and modernity, Turkey had quadrupled the size of its economy, reduced its public debt from 75 percent to 40 percent of GDP, tripled per capita income, and saw its risk premium fall to levels that were envied by most EU member states of the southern periphery at the time. Perhaps more significantly, Turkey was bridging the gap between Anatolia and coastal Turkey, while Europe's divide between East and West was widening.

Of course, there were also more 'traditional' narratives about Turkey, which reduced the success of Turkey 
to a case of 'moral evolution', referred to as 'Islamic Calvinism.' ${ }^{30}$ But the emerging consensus was that Turkey had carved for itself not only a place in Europe, but also a role in Europe.

\section{Turkey as a 'Free Radical' in the Balkans}

Across this historical period, Turkey's role in the Balkans was seen in Europe as part of the broader relationship with the project of European integration. In the context of the Turkish economic and political miracle of the 2000s, Ankara's role in the Balkans was rooted in tradition but held the promise of modernization. In sum, the synthesis between a 'Turk' in the sense of the devout Muslim of Anatolia, and a 'Turk' in the sense of a modern European citizen were achieving their Balkan synthesis.

For decades, Turkey has hosted Muslim refugees from the Balkans, who were viewed as Turks in Bulgaria, Bosnia, or Greece by virtue of their religion if not of their language. Between the late $19^{\text {th }}$ century and early 1920s, four million Tatars, Turks, and Circassians moved to the Ottoman heartland that is today Turkey; about one million Anatolian Turks were forced to move from the Balkans to Turkey, even prior to the formal exchange of populations with Greece in 1923; in excess of 800,000 Muslims moved between 1945 and 1989 to Turkey from Bulgaria and the former Yugoslavia. In sum, Turkey is a regional demographic hub in a region where the terms 'Mus-

\section{Over the course of the last} three years, there has been an atmosphere of "with us or against us," often forcing Balkan states to make mutually exclusive choices

lim' and 'Turk' have often been used interchangeably. ${ }^{31}$

But, economic growth broadened the scope for Turkish protection of these populations in the Balkans. In the 2000s, Turkey emerged as a major power in Official Development Assistance, despite being a middle income country. TİKA (Turkish International Cooperation and Development Agency) has offices in Albania, Serbia, and Bosnia, disbursing aid that protects and promotes the Ottoman legacy in the Balkans, and socially empowers Muslim minority populations. ${ }^{32}$ At the same time, Turkey has become a major source of Foreign Direct Investment (FDI), creating industrial, financial, logistical, and telecommunications value chains across Southeastern Europe. ${ }^{33}$

Passing the \$2 trillion milestone in 2015, Turkey is the region's powerhouse. Turkish trade with Southeastern Europe surged from €364 million in 2002 to $€ 3$ billion in 2016 . $^{34}$ And, Turkish companies in the region were more prone to so-called 'greenfield investment', which came hand-in-hand with employment, 
Turkey no longer appears to invest in the project of European integration either as a process or as an end. Euro-Turkish relations are more frequently framed as a transaction, especially in the current context of a Turkish economic crisis
1992. In sum, Turkey appeared as a champion of regional stability.

However, it would be naïve to believe that Turkish influence was devoid of controversy. The visit of Turkish Foreign Minister Davutoğlu in October 2009 to Bosnia became an opportunity to express a nostalgic vision for the resurgence of an idealized Pax Ottomanica in the Balkans, with common political values, economic interdependence, cooperation, and cultural harmony. That vision was received with some degree of skepticism, ${ }^{37}$ but was also seen as a promise of "zero problems and maximum cooperation with neighbors." After all, the ethnic minority parties Turkey supports in North Macedonia, and Bulgaria have often played a constructive role, advancing minority rights without undermining political stability or indeed the region's European trajectory. However, overt political influence in the Balkans often triggers skepticism, and, at times, a nationalist backlash. ${ }^{38}$

Since the attempted coup in July 2016 in Turkey, the occasional backlash has evolved into a zero-sum confrontation between Brussels and Ankara across the Balkans. The EU does not share the view that the network of the U.S.-based Muslim cleric Fetullah Gülen was behind the movement to overthrow the legally elected government. ${ }^{39}$ At the same time, Turkey has taken the view that EU member states refused to extend solidarity and perhaps even welcomed the prospect of regime change. Over the course of the last three years, there has been an 


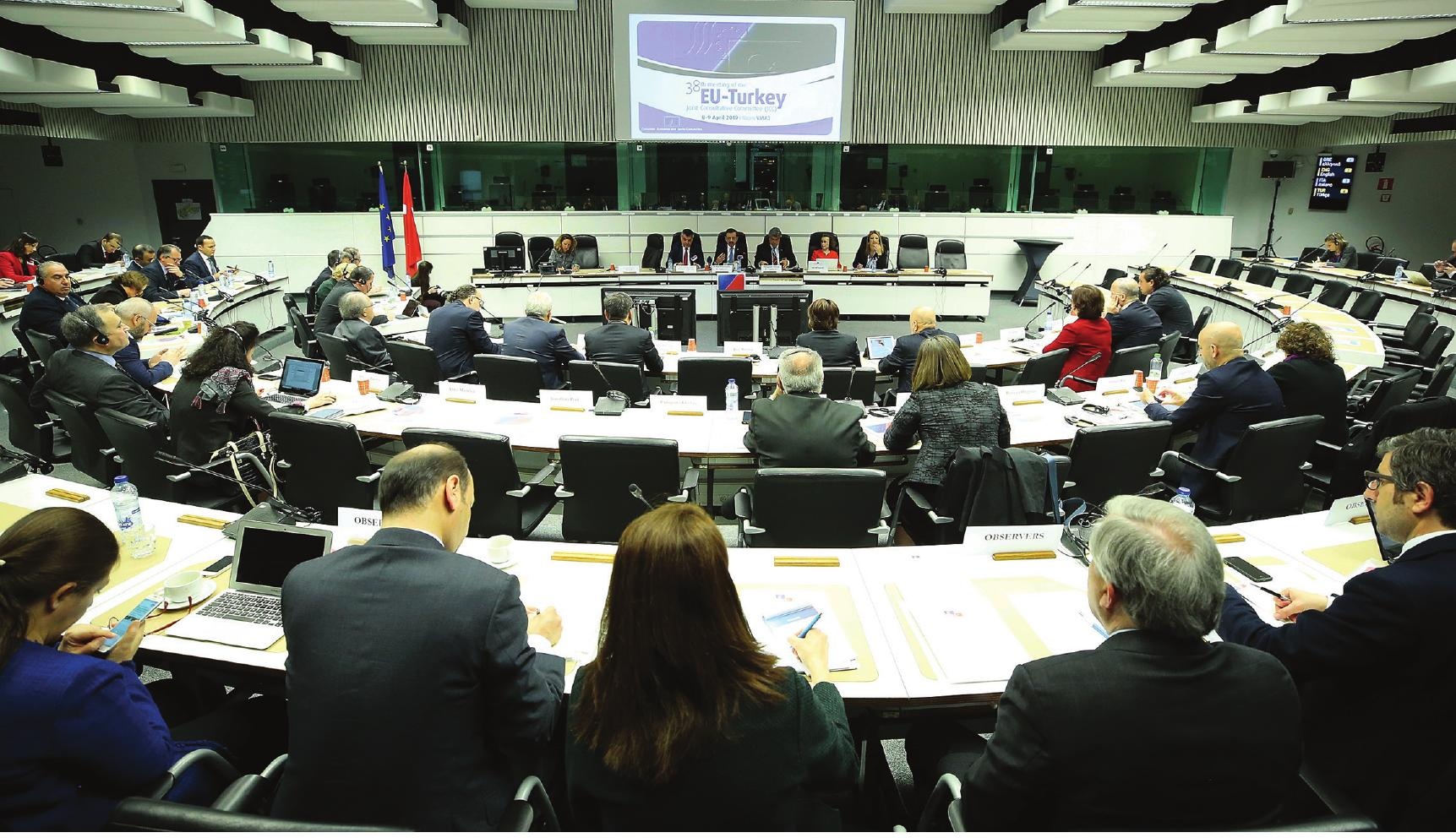

The $38^{\text {th }}$ EU-Turkey Joint Consultative Committee was

atmosphere of "with us or against us," often forcing Balkan states to make mutually exclusive choices.

In March 2018, six Turks residing in Kosovo were "rendered" to Turkey for being members of the so-called Fetullah Gülen Terror Organization (FETÖ). The Turkish intelligence agency MIT and its counterpart in Kosovo organized the transfer, reportedly without the knowledge of Prime Minister Ramush Haradinaj. ${ }^{40}$ The EU condemned the "deportation." 4 That was not an isolated event. In May 2018, President Erdoğan announced a political rally in Sarajevo, which came after the prohibition of similar rallies in EU member states. Once again, Sarajevo was placed in a difficult spot, having to tolerate a symbolic act of Turkish defiance of the EU in Bosnia. ${ }^{42}$ And pressure of this kind is mounting, as Bosnia and Herzegovina is home to private schools founded by the Gülen movement which Ankara has demanded to be closed. ${ }^{43}$
In July 2018, President Recep Tayyip Erdoğan held a swearing-in ceremony in Ankara, following the approval of Turkey's new system. With the exception of Bulgaria, EU leaders largely snubbed the occasion, as the Venice Commission warned about the erosion of checks and balances. However, leaders from North Macedonia, Bosnia and Herzegovina, Albania, Kosovo, and Serbia were present, recognizing Turkey's special gravity in the region, political and economic.

Perhaps more significantly, the confrontation between Turkey and Brussels in the Balkans is gradually taking a more 'systemic turn.' To the extent that Turkey no longer considers itself a stakeholder in the project of European integration, its relationship with Greece is increasingly framed in a more 'geopolitical' language, recently culminating in the public comparison of military capability in terms of troops, tanks, fighter-jets, and submarines between NATO allies. This held in Brussels in April 2019 to work on issues such as the latest situation on

EU-Turkey relations, the Customs Union, and visa dialogue. DURSUN AYDEMIR / AA Photo 
The fear of 'contagion' binds

Turkey systemically to

Europe, but does not inspire

a sense of solidarity that

resonates with the feeling of

a community confrontational dynamic is no longer tamed by an understanding of membership in a common Euro-Atlantic 'community', or indeed the prospect of EU membership.

\section{Interdependence versus Community Building}

Turkey no longer appears to invest in the project of European integration either as a process or as an end. Euro-Turkish relations are more frequently framed as a transaction, especially in the current context of a Turkish economic crisis. According to the Bank of International Settlements, Turkish banks have foreign-denominated loans to the tune of $\$ 148$ billion and $€ 100$ billion. ${ }^{44}$ Much of that debt was issued by European lenders. Spanish banks hold more than $\$ 80$ billion of Turkish debt, French banks $\$ 40$ billion, and Italian banks about $\$ 20$ billion. To put things in perspective, this exposure is comparable to Greek sovereign debt exposure in 2009. ${ }^{45}$

To a certain extent, Turkey's crisis is also a European crisis and a Balkan crisis, as industrial investment and Turkish Official Development Assistance is called into question. ${ }^{46}$ The fear of 'contagion' binds Turkey systemically to Europe, but does not inspire a sense of solidarity that resonates with the feeling of a community. Gone are the references to Islamic Calvinism, as the relationship between Brussels, Ankara, and Washington appear more confrontational. The image of Turkey has backtracked into that of the European other, in cultural, political, geographic, and of course, religious terms. In Turkey too, the prospect of Europeanization has been disowned by the ruling $\mathrm{AK}$ Party movement, but also the nationalist MHP, as a project wholly foreign to Turkish national interests.

The implication for Balkan states, often seen as devoid of political agency, and forced to choose between 'sponsors' is often a mutually exclusive choice between Europe and Turkey. Rather than a regional powerhouse, Turkey is now framed as a factor of Balkanization, that is, political and potentially economic fragmentation that runs contrary to the grand narrative of normative regional alignment. Far from being a European neighborhood, the part of Southeastern Europe that is not assimilated by the $\mathrm{EU}$ is treated as a region in which Turkey asserts its claim to a near abroad, as a great power, often in opposition to Brussels. The difference with the 1990s is that Europeanization no longer appears as a community-building narrative within and around Europe, inclusive of Turkey. Instead, there is a movement towards a more flexible, sovereigntist future for the region 
founded on a cluster of bilateral, limited in scope, and often transactional relations. As countries that traditionally spearheaded the expansion of the single market in the Balkans, such as the UK and the U.S. retreat from the vision of Euro-Atlantic enlargement, countries of the weight and significance of Turkey appear not only as a challenge, but indeed as an alternative.

\section{Endnotes}

1. Ian Manners, "Normative Power Europe: A Contradiction in Terms?" Journal of Common Market Studies, Vol. 40, (2002), pp. 235-258.

2. Edward Best et al., "Effects of Enlargement on the EU's Institutions \& Decision-making: The EU Institutions after Enlargement: Not Quite Business as Usual," in Avery Grahams et al. (eds.), Enlarging the EU: Effects on the New Member States and the EU, (Brussels: Trans European Policy Studies Association, 2009).

3. Ivan Krastev, "Europe Is Facing a Potential Crisis in the Balkans. It Has to Act Soon," The Guardian, (February 21, 2018), retrieved from https://www. theguardian.com/commentisfree/2018/feb/21/ europe-crisis-balkans-eu-membership-russiachina-turkey.

4. Martin Dimitrov, "Balkans Labeled 'Partners' Instead of 'States' for Sofia Summit," BIRN, retrieved April 18, 2018, from http://www.balkaninsight.com/en/article/sofia-summit-declaration-calls-western-balkan-participants-partners--04-23-2018.

5. Ivana Sekularac and Gabriela Baczynska, "EU Woos Western Balkans but Is Coy on Membership," Reuters, (May 16, 2018), retrieved from https://www.reuters.com/article/us-eu-balkans/ eu-woos-western-balkans-but-is-coy-on-membership-idUSKCN1IH2ZE; Gabriela Baczynska and Robin Emmott, "EU Puts off Balkan Membership Talks as France Demands Reforms," Reuters, (June 26, 2018), retrieved from https://uk.reuters. com/article/uk-eu-balkans/eu-puts-off-balkanmembership-talks-as-france-demands-reformsidUKKBN1JM154.

6. "Dutch Referendum Voters Overwhelmingly Reject Closer EU Links to Ukraine," The Guard- ian, (April 7, 2016), retrieved from https://www. theguardian.com/world/2016/apr/06/dutch-voters-reject-closer-eu-links-to-ukraine-in-referendum.

7. Nicola Sarkozy, "Lisbon Treaty: What They Said," (September 30, 2009), retrieved from http://news. bbc.co.uk/1/hi/world/europe/8282241.stm.

8. "Highlights of the EU: Western Balkans Summit in Sofia," European Western Balkans, (May 17, 2018), retrieved from https://europeanwesternbalkans.com/2018/05/17/live-sofia-eu-westernbalkans-summit/.

9. "Special Session with Michael Pompeo, Secretary of State of the United States," World Economic Forum, (January 22, 2019), retrieved from https:// www.weforum.org/events/world-economic-forum-annual-meeting/sessions/us-leadership-inthe-new-global-context.

10. Selim Sazak, "The U.S.-Turkey Relationship Is Worse Off Than You Think," Foreign Policy, (September 11, 2018), retrieved from https://foreignpolicy.com/2018/09/11/the-u-s-turkey-relationship-is-worse-off-than-you-think/.

11. Burhanettin Duran, "Brunson, Gülen and the Unacceptability of an Asymmetrical Relationship," Daily Sabah, (July 22, 2018), retrieved from https:// www.dailysabah.com/columns/duran-burhanettin/2018/07/23/brunson-gulen-and-the-unacceptability-of-an-asymmetrical-relationship.

12. Recep Tayyip Erdoğan, "How Turkey Sees the Crisis With the US," The New York Times, (August 10, 2018), retrieved from https://www.nytimes.com/ 2018/08/10/opinion/turkey-erdogan-trump-crisis-sanctions.html?action=click\&pgtype=Homepage $\&$ clickSource $=$ stor $y$-heading $\&$ module $=$ opinion-c-col-left-region\&region=opinion-c-colleft-region\&WT.nav=opinion-c-col-left-region.

13. Cansu Çamlıbel, "Emekli Tümamiral Cem Gürdeniz: Gülencilerle Mücadele Aczi," Hürriyet, (July 24, 2016), retrieved from http://www.hurriyet. com.tr/gundem/emekli-tumamiral-cem-gurdeniz-gulencilerle-mucadele-aczi-atlantik-korkusundan-ust-akil-roma-40167424.

14. Metin Gürcan, "Turkey Exerts Its Own Leverage in F-35 Jet Standoff with US," AI Monitor, (April 16, 2019), retrieved from https://www.al-monitor. com/pulse/originals/2019/04/turkey-usa-russia-ankara-considers-its-options-s400-crisis.htmI\#ixzz5IJKQDZiq.

15. John Major, "1991 Commons Statement on Maastricht," Ukpol, (April 6, 2018), retrieved from http://www.ukpol.co.uk/john-major-1991-commons-statement-on-maastricht/. 
16. John Peet, "Wider but not Deeper," The Economist, (November 18, 2005), retrieved from https:// www.economist.com/news/2005/11/18/widerbut-not-deeper.

17. Samuel Osborne, "Turkey Joining the EU Is 'Unthinkable', Nicolas Sarkozy Tells Angela Merkel," The Independent, (June 21, 2016), retrieved from https://www.independent.co.uk/news/world/ europe/turkey-joining-the-eu-is-unthinkablenicolas-sarkozy-tells-angela-merkel-a7093601. html.

18. Dan Sabbagh, "Michael Gove Admits Leave Campaign Wrong to Fuel Turkey Fears," The Guardian, (July 16, 2018), retrieved from https://www. theguardian.com/politics/2018/jul/16/michaelgove-admits-leave-was-wrong-to-fuel-immigration-fears.

19. Will Worley, "EU Referendum: David Cameron Points Out the 'Three Lies' Made in Leave Campaign Leaflets," The Independent, (June 19, 2016), retrieved from https://www.independent. co.uk/news/uk/home-news/eu-referendumdavid-cameron-points-out-the-three-liesmade-in-leave-campaign-leaflets-a7090706. html.

20. Dan Bilefsky, "Sarkozy Blocks Key Part of EU Membership," The New York Times, (June 25, 2007), retrieved from https://www.nytimes.com/2007/ 06/25/world/europe/25iht-union.5.6325879. html.

21. "Sarkozy: Turkey Has no Place Inside the European Union," TurkishPress.com, (January 15, 2007), retrieved from http://www.turkishpress. com/news/159133/.

22. "EU Presidency: Sarkozy Talks Turkey with Sweden," Euronews, (July 3, 2009); "No Guarantee of EU Accession for Turkey, Says Merkel," France 24, (February 29, 2010), retrieved from https:// www.france24.com/en/20100329-no-guaranteeeu-accession-turkey-says-merkel.

23. Senem Aydın-Düzgit, Constructions of European Identity: Debates and Discourses on Turkey and the EU, (New York: Palgrave McMillan, 2012), p. 189.

24. Cynthia Kroet, "Resistance against Turkish EU Membership Highest in Germany: Poll," Politico, (May 19, 2017), retrieved from https://www. politico.eu/article/resistance-against-turkish-eumembership-highest-in-germany-poll/.

25. Geoffrey Lewis, The Turkish Language Reform: A Catastrophic Success, (London: Oxford University Press, 1999).
26. COE Assembly Recommendation 1298 on Turkey's respect of commitments to constitutional and legislative reforms (follow up to Recommendation 1266/1995), April 25, 1996.

27. Stefan Krauss, "The European Parliament in EU External Relations: The Customs Union with Turkey," European Foreign Affairs Review, Vol. 5, (2000), pp. 215-237.

28. Ali Çarkoğlu and Barry Rubin (eds.), Religion and Politics in Turkey, (London: Routledge, 2006).

29. José Ignacio Torreblanca, "Neither West nor East, but up," El Pais, (June 10, 2011), retrieved from https://voxeurop.eu/en/content/article/705 041-neither-west-nor-east.

30. "Islamic Calvinists: Change and Conservatism in Central Anatolia," European Stability Initiative, (September 19, 2005), retrieved from https:// www.esiweb.org/pdf/esi_document_id_69.pdf.

31. Ahmed Iç̧duygu, "Rethinking Irregular Migration: Some Demo-Economic Reflections," CARIM Analytic and Synthetic Notes, 2008/72, (2008), retrieved from http://cadmus.eui.eu/bitstream/ handle/1814/10117/CARIM_AS\%26N_2008_72. pdf? sequence $=1$.

32. Rahman Nurdun, "Senior Expert Presentation: Turkish International Cooperation Agency (TIKA)," (April 5-9, 2010).

33. "Turkish Mobile Venture Grows Fast in Albania," Hurriet Daily News, (June 22, 2010); "Diplomatic Diary," Southeastern European Times, (May 20, 2010); Ian Bancroft, "Turkish Delights in the Balkans," Business New Europe, (June 16, 2010), retrieved from https://www.intellinews.com/ turkish-delights-in-the-balkans-500015046/?archive=bne.

34. Zia Weise, "Turkey's Balkan Comeback," Politico, (May 15, 2018), retrieved from https://www. politico.eu/article/turkey-western-balkans-come back-european-union-recep-tayyip-erdogan/.

35. Ivana Sekularac, "Spurned by EU Investors, Balkans Looks to Eager Turkey," Reuters, (May 18, 2018), retrieved from https://www.reuters.com/ article/us-balkans-turkey/spurned-by-eu-investors-balkans-looks-to-eager-turkey-idUSKCN1IJ20Y.

36. Aslı Aydıntaşbaş, "From Myth to Reality: How to Understand Turkey's Role in the Western Balkans," European Council on Foreign Relations, (March 13, 2019), retrieved from https://www. ecfr.eu/publications/summary/from_myth_to_ reality_how_to_understand_turkeys_role_in the_western_balkans. 
37. John Feffer, "Stealth Superpower: How Turkey Is Chasing China to Become the Next Big Thing," Truthdig, (June 13, 2010), retrieved from https:// www.truthdig.com/articles/stealth-superpowerhow-turkey-is-chasing-china-in-bid-to-becomethe-next-big-thing/.

38. Yalçın Bayer, "Turks in Bulgaria Split in Two," Hurriyyet Daily News, (March 9, 2017), retrieved from http://www.hurriyetdailynews.com/opinion/yalcin-bayer/turks-in-bulgaria-split-totwo--110593.

39. Tulay Karadeniz and Tuvan Gumrukcu, "EU Says Needs Concrete Evidence From Turkey to Deem Gulen Network as Terrorist," Reuters, (November 30, 2017), retrieved from https://www. reuters.com/article/us-eu-turkey-security/eusays-needs-concrete-evidence-from-turkeyto-deem-gulen-network-as-terrorist-idUSKBN1DUODX.

40. Semih İdiz, "Erdogan's Risky Bosnia Election Rally Project," Al Monitor, (May 8, 2018), retrieved from http://www.al-monitor.com/pulse/originals/2018/05/turkey-erdogans-risky-bosnia-election-rally-project.html\#ixzz5PPiNxF4l.

41. "EU Criticizes Kosovo, Turkey Over Deportation of Six Erdogan Political Foes," RFE/RL,
(April 4, 2018), retrieved from https://www.rferl. org/a/eu-criticizes-kosovo-turky-over-deportation-six-erdogan-political-foes/29144413.html.

42. Mladen Dragojlovic, "Is Erdogan Going to Hold a Pre-election Rally in Sarajevo?" IBNA, (April 4, 2018), retrieved from https://balkaneu.com/ is-erdogan-going-to-hold-a-pre-election-rally-insarajevo/.

43. Janusz Bugajski, "Is Turkey Destabilizing the Balkans?" CEPA, (April 11, 2018), retrieved from https://www.cepa.org/turkey-balkans.

44. "Angela Merkel Tells Turkey to Keep Hands off Central Bank," Deutsche Welle, (August 18, 2018), retrieved from https://www.dw.com/en/angelamerkel-urges-turkey-to-keep-hands-off-centralbank/a-45069339.

45. Balaz Koranyi, "European Banks Hammered for Turkish Exposure," Reuters, (August 10, 2018), retrieved from https://uk.reuters.com/article/ uk-turkey-currency-europe-banks/ecb-growingconcerned-over-euro-zone-bank-exposure-toturkey-ft-idUKKBN1KVOVO?il=0.

46. "Contagion Fears in Balkans as Turkish Lira Plummets," Ahval, (August 30, 2018), retrieved from https://ahvalnews.com/turkey-crisis/contagion-fears-balkans-turkish-lira-plummets. 

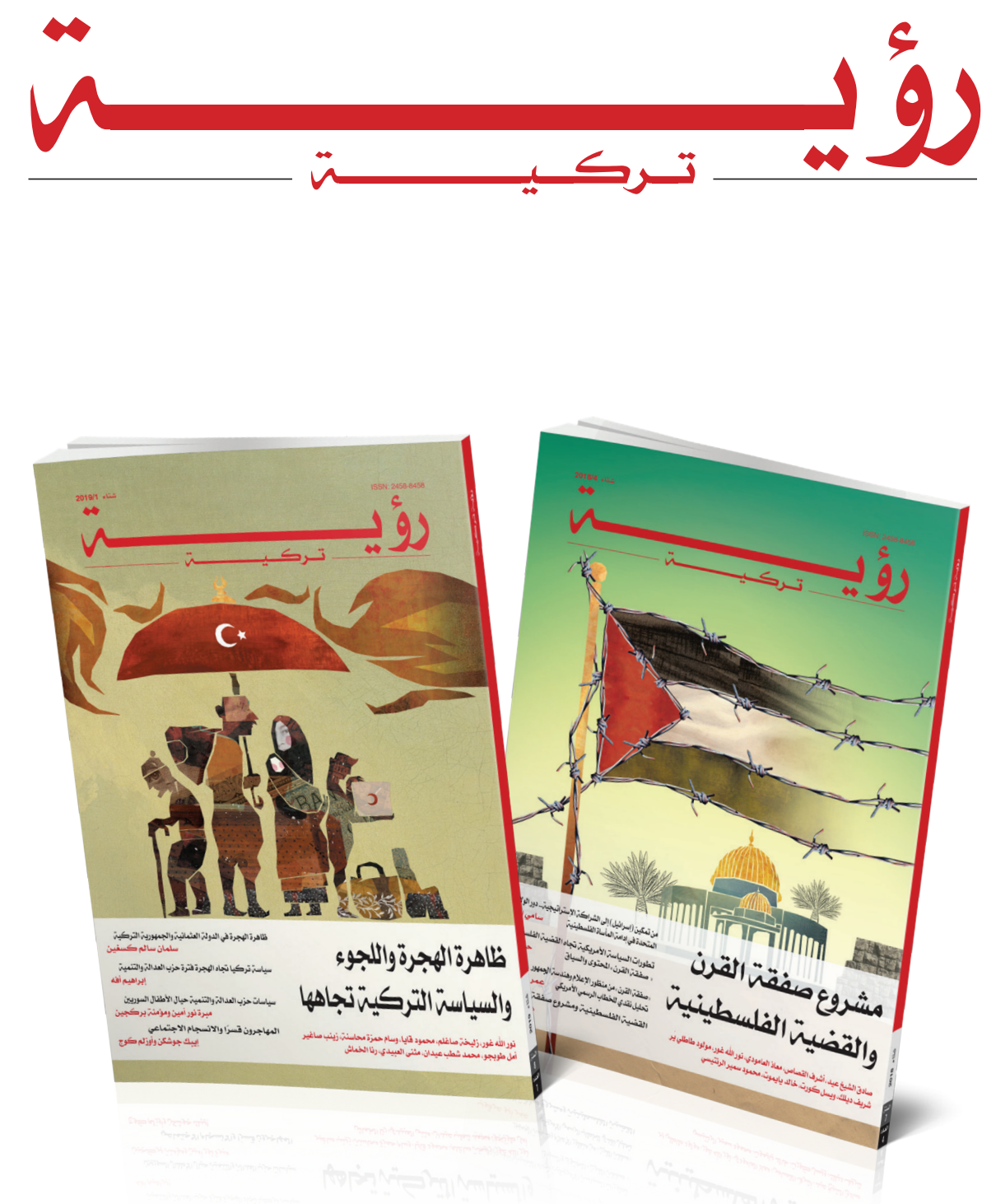

Rouya Turkiyyah is a quarterly academic journal published by SETA Foundation since 2012. It covers a broad range of topics related to domestic and foreign policy of the Middle Eastern countries focusing mostly in their politics, economy and social problems. Rouya Turkiyyah seeks to furnish a new regional perspective, through the allocation of new spaces for serious discussions on the World Affairs but more specifically in the Middle East affairs. 